\title{
18S ribosomal DNA-based PCR identification of Neoparamoeba pemaquidensis, the agent of amoebic gill disease in sea-farmed salmonids
}

\author{
Frank Y. K. Wong ${ }^{1}$, Jeremy Carson ${ }^{2}$, Nicholas G. Elliott ${ }^{1, *}$ \\ ${ }^{1}$ Aquaculture and Biotechnology, CSIRO Marine Research, GPO Box 1538, Hobart 7001, Tasmania, Australia \\ ${ }^{2}$ Fish Health Unit of the Tasmanian Aquaculture and Fisheries Institute, University of Tasmania, PO Box 46, \\ Kings Meadows 7249, Tasmania, Australia
}

\begin{abstract}
Neoparamoeba pemaquidensis is a parasomal amoeboid protozoan identified as the agent of amoebic gill disease (AGD) in Atlantic salmon Salmo salar reared in sea-pens in Tasmania, Australia, and coho salmon Oncorhynchus kisutch farmed on the west coast of the USA. Outbreaks of AGD caused by immunologically cross-reactive paramoebae have also been reported in seafarmed salmonids in several other countries. Complete 18S rDNA sequences were determined for respective paramoebae isolated from infected gills of salmon from Tasmania and Ireland, and $N$. pemaquidensis isolates from the USA and UK, including representative free-living isolates. Alignments over 2110 bp revealed 98.1 to $99.0 \%$ sequence similarities among isolates, confirming that paramoebae implicated in AGD in geographically distant countries were homologous and belonged to the same species, $N$. pemaquidensis. The results supported previous findings that $N$. pemaquidensis exists as a widely distributed, amphizoic marine protozoan. Partial 18S rDNA sequences were obtained for the ultrastructurally similar species, $N$. aestuarina, and for the morphologically similar but non-parasomal amoeba Pseudoparamoeba pagei. N. aestuarina had 95.3 to $95.7 \%$ sequence similarities with $N$. pemaquidensis strains, which distinguished 2 closely related but separate species. Neoparamoeba spp. were not analogous to $P$. pagei or to other marine Gymnamoebia. We designed 4 oligonucleotide primers based on elucidated 18S rDNA sequences and applied them to single-step and nested 2-step PCR protocols developed to identify N. pemaquidensis to the exclusion of apparently closely related and non-related protistan taxa. Nested PCR was able to detect the AGD parasite from non-purified, culture-enriched net microfouling samples from Atlantic salmon sea-pens in Tasmania, and confirmed that $N$. pemaquidensis was also responsible for AGD in chinook salmon $O$. tshawytscha in New Zealand. Our sequence and PCR analyses have now shown that AGD affecting 3 different salmonid species farmed in 4 countries are associated with $N$. pemaquidensis. A speciesspecific diagnostic PCR provides for the first time, a highly specific detection and identification assay for $N$. pemaquidensis that will facilitate future ecological and epidemiological studies of AGD.
\end{abstract}

KEY WORDS: Amoebic gill disease - Neoparamoeba pemaquidensis - Neoparamoeba aestuarina · $18 \mathrm{~S}$ ribosomal DNA $\cdot \mathrm{PCR} \cdot$ Salmo salar $\cdot$ Salmonids

\section{INTRODUCTION}

Neoparamoeba pemaquidensis (Page, 1987) is an amoeboid protozoan that causes amoebic gill disease (AGD) in salmonids sea-farmed in several different countries (Munday et al. 2001). AGD remains the most important parasitic disease affecting sea-farmed Atlantic salmon Salmo salar L. and rainbow trout Oncorhynchus mykiss Walbaum in Tasmania, Australia (Munday et al. 1990, 2001). Outbreaks of AGD have also been reported in Atlantic salmon farmed in Chile, France (Clark \& Nowak 1999), Ireland (Rodger \& McArdle 1996, Palmer et al. 1997) and Spain (Munday et al. 2001), and in coho salmon O. kisutch Walbaum in 
Washington State and California, USA (Kent et al. 1988), chinook salmon O. tshawytscha Walbaum in New Zealand (C. Anderson pers. comm.), and in rainbow and brown trout $S$. trutta L. in France (Findlay et al. 1995). The disease appears to be uniquely enzootic in southeast Tasmania, where Atlantic salmon reared in sea-pens are affected by recurring, seasonally influenced outbreaks (Clark \& Nowak 1999). In contrast, AGD has only occurred as sporadic or minor outbreaks in other regions. AGD due to Neoparamoeba sp. have also affected non-salmonid fishes, including turbot, Scophthalmus maximus L. and European seabass Dicentrarchus labrax L. reared in seawater in Spain and the Mediterranean respectively (Dyková et al. 1995, 1998, Dyková \& Novoa 2001).

Neoparamoeba pemaquidensis belongs to a group of exclusively marine amoebae formerly classified within the genus Paramoeba Schaudinn, 1896 (Cann \& Page 1982, Page 1987). The paramoebae are distinguished by possession of 1 or more DNA-positive, membranebound inclusions located adjacent to the cell nucleus and known as parasomes. The genus Neoparamoeba was proposed by Page (1987) and distinguished the species $N$. pemaquidensis and $N$. aestuarina from $P$. eilhardi (type species of genus Paramoeba) based on cell surface structural and other morphological and ultrastructural differences. Both $N$. pemaquidensis and $N$. aestuarina are widely distributed species and have commonly been isolated as free-living trophozoites from a range of coastal marine habitats around the world (Page 1973, Cann \& Page 1982). Although the 2 species have been separated based on small differences in physical and in vitro growth characteristics (Page 1970), there is little to differentiate them ultrastructurally (Cann \& Page 1982). As a consequence, there has been some confusion as to whether N. aestuarina also exists in parasitic form and causes AGD similar to that associated with $N$. pemaquidensis (Dyková et al. 2000). The occurrence of $N$. pemaquidensis in both parasitic and free-living forms has indicated that this is an amphizoic species (Page 1974, Roubal et al. 1989).

AGD-affected fishes develop characteristically similar gill cytopathology, regardless of the fish species (Kent et al. 1988, Roubal et al. 1989, Dyková et al. 1998, Munday et al. 2001). Infected gill filaments exhibit epithelial hyperplasia and hypertrophy leading to complete fusion of the secondary lamellae. Infecting amoeba cells are generally abundant within the interlamellar spaces associated with the hyperplastic epithelium. Consequently, histopathological examination of gill sections has served as a reliable but nonspecific method for diagnosis of AGD and for confirming the presence of infecting amoeba cells (Clark \& Nowak 1999). Howard \& Carson (1993) developed an indirect fluorescent antibody test (IFAT) based on polyclonal antisera raised against Neoparamoeba pemaquidensis isolated from AGD-affected Atlantic salmon in Tasmania. IFAT is applied to the serological screening of gill sections and mucous smears for N. pemaquidensis, and has been used to identify gill-associated paramoeba cells and isolates from other countries where AGD has been reported (Rodger \& McArdle 1996, Palmer et al. 1997, Munday et al. 2001). IFAT remains the 'gold standard' test for confirming AGD cases in Tasmanian salmon farms, although an alternative high-throughput immuno-dot blot test has recently also been developed by Douglas-Helders et al. (2001). Although immunologically-based screening has proved useful in the diagnosis of AGD in infected gill samples (Zilberg \& Munday 2000), its application to the specific identification of $N$. pemaquidensis has been limited by inter-species cross-reactivity of the available polyclonal antisera. In particular, antisera developed against $N$. pemaquidensis to date have cross-reacted with $N$. aestuarina and the non-parasomal amoeba Pseudoparamoeba pagei (Douglas-Helders et al. 2001). These species have been found in the same coastal habitats as the implicated AGD parasite (Page 1970,1979 ) and have the potential to interfere with cross-specific identification tests applied to environmental samples.

Diagnostic PCR primers targeting specific regions of the 18S (small subunit) ribosomal RNA gene have frequently been used for the identification and detection of fish parasites from the host and from environmental samples (Cunningham 2002). In this study, we determined the $18 \mathrm{~S}$ rDNA sequences of representative strains of Neoparamoeba pemaquidensis (including AGD-associated and free-living isolates), and of representative strains of $N$. aestuarina and Pseudoparamoeba pagei. Comparative 18S rDNA sequence analysis was used to clarify the relationships between AGD isolates of $N$. pemaquidensis from different countries of origin and with $N$. aestuarina, and was applied to the development of specific diagnostic oligonucleotides for $N$. pemaquidensis. The development of a species-specific nested PCR protocol useful for the identification of $N$. pemaquidensis from new AGD and free-living paramoeba isolates, and with potential application for direct detection of the parasite from fish-farm environmental samples is described.

\section{MATERIALS AND METHODS}

Strains and culture maintenance. Neoparamoeba pemaquidensis isolates that had been culture-purified from AGD-infected Atlantic salmon gills were used for analysis in this study (Table 1). These included 4 sepa- 
Table 1. Neoparamoeba spp. and other marine amoeba strains and isolates used for DNA analysis in this study. ATCC 50172 is an amoebic gill disease (AGD) isolate from coho salmon (Kent et al. 1988), while all other AGD isolates were from Atlantic salmon

\begin{tabular}{|c|c|c|c|}
\hline Species & Strain & Source & Origin \\
\hline $\begin{array}{l}\text { Neoparamoeba } \\
\text { pemaquidensis }\end{array}$ & $\begin{array}{l}\text { ATCC } 50172 \\
\text { ATCC } 30735 \\
\text { CCAP 1560-4 } \\
\text { CCAP 1560-5 } \\
\text { PA } 027 \\
\text { PA } 010 \\
\text { PA } 011 \\
\text { PA } 111 \\
\text { AVG } 8194\end{array}$ & $\begin{array}{l}\text { Gills, AGD } \\
\text { Free-living }^{\text {a }} \\
\text { Free-living } \\
\text { Free-living } \\
\text { Gills, AGD } \\
\text { Gills, AGD } \\
\text { Gills, AGD } \\
\text { Gills, AGD } \\
\text { Gills, AGD }\end{array}$ & $\begin{array}{l}\text { Washington, USA } \\
\text { Virginia, USA } \\
\text { Wales, UK } \\
\text { Wales, UK } \\
\text { Tasmania, Australia } \\
\text { Tasmania, Australia } \\
\text { Tasmania, Australia } \\
\text { Tasmania, Australia } \\
\text { Ireland, UK }\end{array}$ \\
\hline Neoparamoeba aestuarina & CCAP 1560-7 & Free-living & Portugal \\
\hline Pseudoparamoeba pagei & CCAP 1566-1 & Free-living & England, UK \\
\hline Unspeciated amoeba $^{\mathrm{b}}$ & $\begin{array}{l}\text { UP } 1-6 \\
\text { UP } 3 a-4 \\
\text { UP } 4 a-2 \\
\text { UP } 4 b-5\end{array}$ & $\begin{array}{l}\text { Gills, AGD } \\
\text { Gills, AGD } \\
\text { Gills, AGD } \\
\text { Gills, AGD }\end{array}$ & $\begin{array}{l}\text { Tasmania, Australia } \\
\text { Tasmania, Australia } \\
\text { Tasmania, Australia } \\
\text { Tasmania, Australia }\end{array}$ \\
\hline \multicolumn{4}{|c|}{$\begin{array}{l}\text { a Originally cultured from free-living cells in marine environments } \\
\text { bIdentified by } 18 \text { S rDNA sequences as Paraflabellula hoguae (Amaral Zettler et } \\
\text { al. 2000) }\end{array}$} \\
\hline
\end{tabular}

Reference Neoparamoeba spp. and Pseudoparamoeba sp. cultures from ATCC and CCAP were grown xenically on MYS agar with supplied bacterial substrates according to suppliers' instructions.

Preparation of cellular DNA. Following 1 to $2 \mathrm{wk}$ incubation, cells were harvested by adding $3 \mathrm{ml}$ filtersterilised $(0.2 \mu \mathrm{m})$ seawater or sterile phosphate-buffered saline (PBS), $\mathrm{pH} 7.4$, to each plate and scraping cells into suspension using a sterile spreader. Of the suspended cells, a $1 \mathrm{ml}$ aliquot was pelleted at $1000 \times g$ for $15 \mathrm{~min}$, and washed twice with $700 \mu \mathrm{l}$ ice-cold PBS followed by centrifugation at $12000 \times g$ for $15 \mathrm{~min}$. Ethanol-preserved cells of Neoparamoeba pemaquidensis Strain AVG 8194 were pelleted directly for DNA extraction. Isolation of genomic DNA followed standard protocols of Ausubel et al. (1998). Cells were suspended in $600 \mu$ lysis buffer $(10 \mathrm{mM}$ Tris- $\mathrm{HCl}, \mathrm{pH}$ 8.0; 1 mM EDTA, pH 8.0; 0.5\% sodium dodecyl sulphate; $0.1 \mathrm{mg}$ proteinase $\mathrm{K} \mathrm{ml}^{-1}$ ) and incubated at $65^{\circ} \mathrm{C}$ for $2 \mathrm{~h}$ before addition of $100 \mu \mathrm{l} 5 \mathrm{M}$ $\mathrm{NaCl}$ and $80 \mu \mathrm{l} 10 \%$ hexadecyltrimethylammonium bromide (CTAB)-0.7 M NaCl solution, and reincubated at $65^{\circ} \mathrm{C}$ for $30 \mathrm{~min}$. DNA was extracted with phenolchloroform-isoamyl alcohol and precipitated overnight at $-20^{\circ} \mathrm{C}$ with isopropanol. The DNA pellet was washed twice in ice-cold $70 \%$ ethanol and resuspended in $100 \mu \mathrm{l}$ sterile MilliQ (Millipore) water. Total cellular DNA was used directly as template for PCR.

Amplification and sequencing of 18S rDNA. Universal oligonucleotide primers complementary to conserved regions of the eukaryotic 18S rRNA gene were used for PCR amplification and DNA sequencing in this study (Elwood et al. 1985, Medlin et al. 1988, Hillis \& Dixon 1991). In most cases, amplification of the entire 18S rRNA gene was achieved using the primer pair of Medlin et al. (1988). These primers anneal to conserved sequences at the 5' and 3 ' termini of the gene respectively. All primers were commercially synthesised by Genset Pacific, Lismore, Australia. The standard $50 \mu \mathrm{l}$ PCR reaction mix consisted of $0.2 \mu \mathrm{l}$ (1 U) of Amplitaq Gold ${ }^{\mathrm{TM}}$ DNA polymerase (PerkinElmer Applied Biosystems), $5 \mu 10 \times$ PCR Gold ${ }^{\mathrm{TM}}$ buffer, $5 \mu \mathrm{l}(2.5 \mathrm{mM})$ of $25 \mathrm{mM} \mathrm{MgCl}_{2}$ solution, $1 \mu \mathrm{l}$ (0.2 mM) of $10 \mathrm{mM}$ dNTPs (Promega), $1.5 \mu \mathrm{l}(0.3 \mu \mathrm{M})$ each of $10 \mu \mathrm{M}$ forward and reverse primers respectively, $30.8 \mu \mathrm{l}$ of MilliQ water, and $5 \mu \mathrm{l}$ of cellular DNA template. Appropriate amplification control reactions 
were included with every PCR preparation. Standard PCR conditions consisted of an initial denaturation and activation at $95^{\circ} \mathrm{C}$ for $10 \mathrm{~min}$, followed by 35 cycles of $94^{\circ} \mathrm{C}$ for $1 \mathrm{~min}, 48^{\circ} \mathrm{C}$ for $1 \mathrm{~min}$, and $68^{\circ} \mathrm{C}$ for $1.5 \mathrm{~min}$, and a final extension step of $72^{\circ} \mathrm{C}$ for $10 \mathrm{~min}$. PCR amplifications were performed using a GeneAmp ${ }^{\circledR}$ System 9700 thermocycler (PE Applied Biosystems). PCR products were visualised on a $2 \%$ agarose gel stained with $0.5 \mu \mathrm{g}$ ethidium bromide $\mathrm{ml}^{-1}$. We used a $1 \mathrm{~kb}$ DNA ladder (New England Biolabs or Invitrogen Life Technologies) as molecular size marker.

Amplified 18S rDNA was purified for sequencing using spin columns from the QIAquick PCR purification kit (Qiagen) according to the manufacturer's instructions. Purified DNA was quantified using the GeneQuantpro RNA/DNA calculator (Amersham Pharmacia Biotech). Sequencing reactions were performed according to manufacturer's instructions using the ABI BigDye ${ }^{\mathrm{TM}}$ Terminator Cycle Sequencing Ready Reaction kit (PE Applied Biosystems) and cycle amplification performed in the GeneAmp ${ }^{\circledR}$ System 9700 thermocycler. DNA sequence data was obtained with the ABI Prism ${ }^{\mathrm{TM}} 377$ DNA sequencer (PE Applied Biosystems). Both coding and non-coding strands of the $18 \mathrm{~S}$ rDNA were independently sequenced and checked against the complementary strands for each amoeba strain. Overlapping sequences obtained with different primers were also compared. Sequence discrepancies were checked by repeat-sequencing of the DNA region in question using the appropriate primers.

Sequence analysis. Analysis and alignment of DNA sequences were performed using the Sequence Navigator $^{\mathrm{TM}}$ Version 1.0.1 program (PE Applied Biosystems). Sequences generated in this study were subjected to a BLAST sequence similarity search (Altschul et al. 1990) via the National Center for Biotechnology Information (NCBI) web server (www.ncbi.nlm.nih.gov), to confirm that $18 \mathrm{~S}$ rRNA gene sequences were obtained and to screen for potentially related taxa. Sequences from Neoparamoeba spp. and strains generated in this study were aligned and compared against each other, and also with the 18S rDNA sequences of selected Gymnamoebia (Page 1987) and other relevant protistan taxa available from the GenBank sequence database. Percentage sequence similarities between the respective Neoparamoeba spp. and strains were calculated as described by Stothard et al. (1998).

Development of PCR primers for Neoparamoeba pemaquidensis. Complete $18 \mathrm{~S} \mathrm{rDNA}$ sequences obtained for $N$. pemaquidensis were examined for suitable annealing sites for the design of species-specific oligonucleotide primers. Suitable target regions consisted of sequences that hybridise between the various $N$. pemaquidensis stains and isolates, but contain sufficient nucleotide differences to distinguish this species from other taxa. Deduced primer sequences were examined for possible complementarity with $18 \mathrm{~S}$ rDNA of non-target amoebae (Table 1), and subjected to random BLAST sequence similarity searches to determine if homologous or related sequences were present in the existing sequence databases. Candidate primers and potential primer pairs were also checked to minimise self-complementarity. We synthesised (Genset Pacific) 4 oligonucleotides targeting suitable regions of the 18S rDNA of $N$. pemaquidensis for evaluation (Table 2); 3 forward primers (Table 2) were respectively paired with the reverse primer $\mathrm{rNp}-\mathrm{Hx} 49$ and tested for amplification of $N$. pemaquidensis $18 \mathrm{~S}$ rDNA. Optimal PCR conditions were the same for all 3 primer sets and similar to the standard conditions for 18S rDNA amplification, with the exceptions that $0.1 \mu \mathrm{M}$ of each primer was used per reaction and the stringency of annealing was increased to $58^{\circ} \mathrm{C}$ during the PCR cycling steps. Direct-sequence analyses showed that only primer fNp-Hxe23b1 would be able to distinguish $N$. pemaquidensis from the closely related species, $N$. aestuarina. Primer fNp-Hxe23b1 has 7 non-complementary bases within the 24-base primer annealing site in $N$. aestuarina 18S rDNA (Table 3). In contrast, $N$. aestuarina possessed near identical sequences to $N$. pemaquidensis at the respective annealing sites of primers fNp-Hxe23a1, fNp-Hx43a1, and rNp-Hx49.

Nested PCR protocol for Neoparamoeba pemaquidensis. Analyses of initial non-purified (mixed) cultures obtained from environmental samples have suggested that $N$. pemaquidensis cells occur at low concentrations (Tan et al. 2002). A nested 2-step PCR procedure was developed to maximise the chances of positive detection of the AGD parasite from these samples. Total cellular DNA extracted from these samples were subjected to a primary (first-round) PCR amplification using the forward primer fNp-Hxe23a1 and the universal 18S rDNA reverse primer of Medlin et al.

Table 2. Oligonucleotide primers developed for Neoparamoeba pemaquidensis diagnostic PCR. Prefix f: forward primers annealing to coding strand of 18S rRNA gene; Prefix r: reverse primer annealing to non-coding coding strand. Positions correspond to nucleotide positions on 18S rDNA sequence of N. pemaquidensis Strain ATCC 50172 obtained in this study (GenBank Accession No. AF371971)

\begin{tabular}{|lll|}
\hline Primer & Sequence $\left(5^{\prime}-3^{\prime}\right)$ & Positions \\
\hline fNp-Hxe23a1 & CATCTCCTTACTAGACTTTCATG & $715-737$ \\
fNp-Hxe23b1 & GTGAGTGATGAGTAGACCTACTGG & $780-803$ \\
fNp-Hx43a1 & GTGATGCAAATGATTACATCCG & $1540-1561$ \\
rNp-Hx49 & CACAACAAACTCGCTCTACCC & $2009-2030$ \\
\hline
\end{tabular}


Table 3. Neoparamoeba spp. Respective 18S rDNA sequences corresponding to annealing positions of $N$. pemaquidensis diagnostic primer fNp-Hxe23b1. Dots indicate matching bases; non-matching bases are highlighted

\begin{tabular}{|c|c|}
\hline Species/primer & Sequence $\left(5^{\prime}-3^{\prime}\right)$ \\
\hline N. pemaquidensis & GTGAGTGATGAGTAGACCTAYTGG \\
\hline Primer fNp-Hxe23b1 & 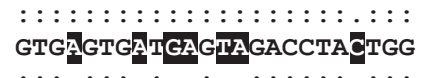 \\
\hline N. aestuarina & $\begin{array}{l}::::: \quad: \quad: \quad:::::: \quad::: \\
\text { GTGCGTGETAGGAGGACCTATTGG }\end{array}$ \\
\hline
\end{tabular}

(1988) and standard reaction and cycling conditions previously described. One $\mu \mathrm{l}$ of the ca. $1.4 \mathrm{~kb}$ primary PCR reaction product was used as template for a secondary (second-round) nested PCR utilising the forward primer fNp-Hxe23b1 and reverse primer rNpHx49 (Table 2) to amplify $N$. pemaquidensis $18 \mathrm{~S}$ rDNA to the exclusion of other species. Reaction and cycling conditions $\left(58^{\circ} \mathrm{C}\right.$ annealing) for secondary amplification were similar to those already described for $N$. pemaquidensis-specific PCR.

Specificity of the nested PCR was tested by screening against cellular DNA extracts from the target and non-target amoebae in Table 1. Genomic DNA from Atlantic salmon was also subjected to the nested PCR to test for possible cross-reactivity, since the procedure was likely to be applied to samples associated with salmon tissues. Specificity of the secondary primer pair, fNp-Hxe23b1 and rNp-Hx49, when used in the nested 2-step PCR protocol, was compared to singlestep PCR amplification using these primers. Efficacy of the nested PCR was evaluated using whole cells of Neoparamoeba pemaquidensis Strain PA 027 suspended in filter-sterilised, natural seawater. Duplicate DNA extractions were performed on respective serial 2-fold dilutions starting from a suspension of 2560 cells down to 40 cells, and $30 \mathrm{ng}$ cellular DNA was used as the primary PCR template.

PCR of Neoparamoeba pemaquidensis from salmon farm samples. The $N$. pemaquidensis-specific nested PCR was applied to samples processed from biofouling contamination films on marine net-pens. Microfouling fractions (biofilm) on submersed pen netting were sampled from commercial Atlantic salmon farm sites in southeast Tasmania during biofouling field surveys for N. pemaquidensis (Tan et al. 2002, Douglas-Helders et al. 2003). Biofilm was swabbed from lifted near-surface netting and transferred onto MYS agar (Tan et al. 2002). Plates incubated at $20^{\circ} \mathrm{C}$ for 7 to $10 \mathrm{~d}$ were harvested, and cell suspensions were subjected to total DNA extraction and PCR analysis. The net biofilm sampled from 1 farm site formed part of a $10 \mathrm{wk}$ survey to investigate the effects of antifouling paint treatments on the distribution of $N$. pemaquidensis on seapen netting (Douglas-Helders et al. 2003). Samples tested by PCR comprised culture-enriched biofilm smears collected from 5 separate marine net pens on Weeks 2 and 8 of that study. Netting from these pens had either been treated with a water-based synthetic latex (Wattyl, Australia) antifouling paint (1 pen: P1), a copper-based (Hempel Paint, Australia) antifouling paint (2 pens: P2 and P3), or left as untreated controls (2 pens: P4 and P5). In addition, 4 ethanol-preserved amoebae suspensions cultured from gills of chinook salmon Oncorhynchus tshawytscha in New Zealand were received for PCR testing. These cultures were originally derived from sea-penned fish in Marlborough Sounds, New Zealand, that were affected by an outbreak of AGD. Putative identification of a paramoeboid gill parasite had been made by gill histology and IFAT identification of the cultures (C. Anderson pers. comm.).

Sequence verification of PCR products. The secondround PCR products of arbitrarily selected, positive, farm-associated samples were subjected to DNA sequencing to verify that the respective amplicons were derived from Neoparamoeba pemaquidensis. Sequences were obtained using the diagnostic primers in Table 2, and universal eukaryotic 18S rDNA primers (Elwood et al. 1985) that anneal to positions internal to the expected PCR product. DNA sequences from PCRpositive samples were aligned and compared to $18 \mathrm{~S}$ rDNA sequences of Neoparamoeba spp., and homologies were assessed.

\section{RESULTS}

\section{$18 \mathrm{~S}$ rDNA sequence analysis of marine amoebae}

PCR amplification using the universal 18S rRNA gene primers of Medlin et al. (1988) and cellular DNA from Neoparamoeba pemaquidensis strains produced 18S rDNA amplicons of ca. $2.1 \mathrm{~kb}$ in size. Complete 18S rDNA sequences were obtained for 4 AGD-associated $N$. pemaquidensis isolates from Tasmania by direct sequencing of the amplified gene products. In each case, $2109 \mathrm{bp}$ of the 18S rDNA sequence were obtained for comparative analyses. All 4 Tasmanian isolates possessed identical sequences, and PA 027 was selected as the representative Tasmanian AGD strain in the present study. Respective 18S rDNA amplicons from the Irish AGD isolate, and from freeliving and AGD-associated strains from the USA and UK, were similar in molecular size to that of PA 027. Complete 18S rDNA sequences of 2107 to $2110 \mathrm{bp}$ 
were obtained for these strains. Free-living N. pemaquidensis Strains CCAP 1560-4 and CCAP 1560-5 were isolated from the same region in Wales and had identical 18S rDNA sequences. All other $N$. pemaquidensis strains tested had highly similar but non-identical sequences. $N$. aestuarina Strain CCAP 1560-7 produced a ca. $2.1 \mathrm{~kb}$ PCR product from which a near-complete 18S rDNA sequence of $1901 \mathrm{bp}$ was obtained. In comparison, amplified 18S rDNA from Pseudoparamoeba pagei and 4 unidentified gill amoeba isolates were smaller in size at ca. $1.8 \mathrm{~kb}$. A partial gene sequence consisting of $1352 \mathrm{bp}$ was obtained for $P$. pagei Strain 1566-1, while complete $18 \mathrm{~S}$ rDNA sequences of $1861 \mathrm{bp}$ were obtained for the unidentified isolates. The 4 unspeciated gill isolates shared identical 18S rDNA sequences, and comparison with available sequences in the GenBank database revealed near identical $(99.9 \%)$ sequence similarity with the non-parasomal leptomyxid amoeba species Paraflabellula hoguae (GenBank Accession No. AF293899).

The complete 18S rDNA sequences obtained for Neoparamoeba pemaquidensis Strains PA 027, AVG 8194, CCAP 1560-4, CCAP 1560-5, ATCC 50172, and ATCC 30735 in this study were deposited with GenBank under Accession Nos. AF371967 through to AF371972 respectively. Partially completed 18S rDNA sequences were deposited with GenBank for $N$. aestuarina CCAP 1560-7 (Accession No. AF371973) and Pseudoparamoeba pagei CCAP 1566-1 (Accession No. AY277798). The complete 18S rDNA sequence obtained for putative Paraflabellula hoguae isolate, UP1-6 from gills of Atlantic salmon farmed in Tasmania was deposited under Accession No. AY277797.

\section{Sequence homogeneity among Neoparamoeba pemaquidensis strains}

The respective 18S rRNA genes of AGD-associated Neoparamoeba pemaquidensis strains from Tasmania, Ireland and the USA, and reference free-living strains from the USA and UK, shared high levels of sequence homology (98.1 to $99.0 \%$ sequence similarities). These levels of sequence similarities confirmed that AGD isolates from geographically distant countries and infecting at least 2 salmonid species belonged to the same paramoeba species. Comparative 18S rDNA analysis showed that $N$. aestuarina is closely related to but a distinct species from $N$. pemaquidensis. Comparison of the 1901 bp $18 \mathrm{~S}$ rDNA segment of $N$. aestuarina CCAP 1560-7 revealed 95.3 to $95.7 \%$ sequence similarities with analogous aligned sequences of the various $N$. pemaquidensis strains. The $18 \mathrm{~S}$ rDNA sequences obtained for $N$. pemaquidensis and $N$. aestuarina were not homologous to any other marine Gymnamoebia or other protistan taxa when screened against the GenBank database, and represented new and unique sequence data for these species at the time of this study.

\section{Identification of Neoparamoeba pemaquidensis using diagnostic PCR primers}

The candidate Neoparamoeba pemaquidensis diagnostic primer sets fNp-Hxe23a1/rNp-Hx49, fNp-Hxe23b1/rNp-Hx49, and fNp-Hx43a1/rNp-Hx49 (Table 2) each produced a specific amplification product when tested using the standard PCR protocol on cellular DNA prepared from the respective $N$. pemaquidensis strains (Fig. 1), regardless of the source or country of
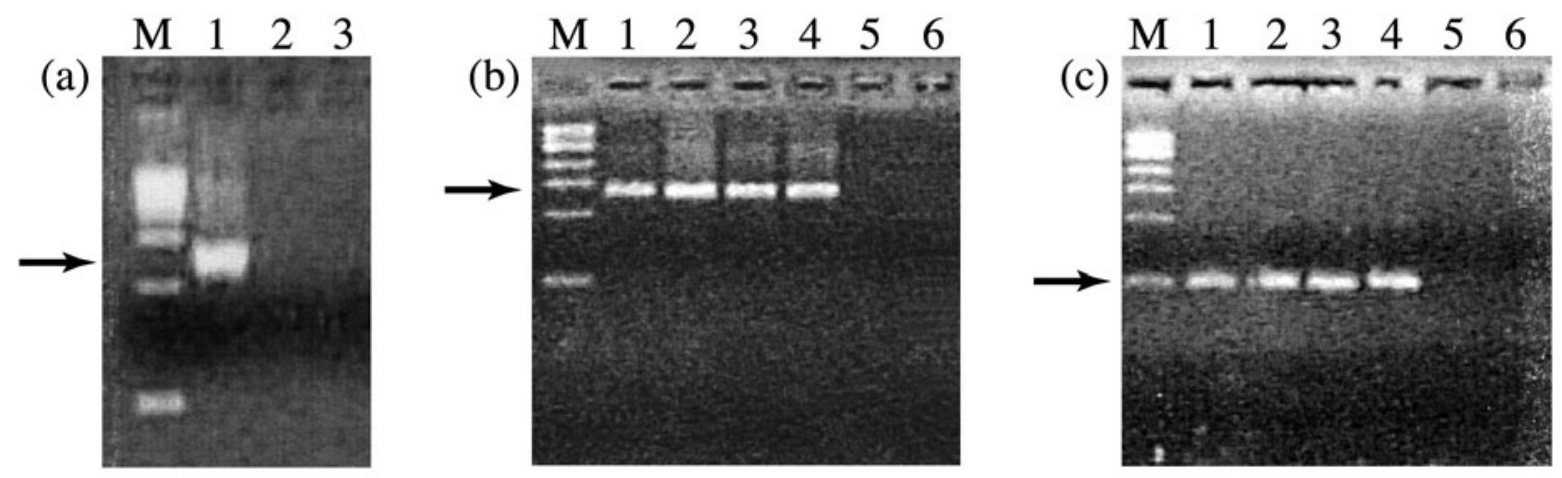

Fig. 1. (a) PCR with primer set fNp-Hxe23a1/rNp-Hx49 showing specific amplification of Neoparamoeba pemaquidensis Strain ATCC 50172 (Lane 1), to exclusion of Pseudoparamoeba pagei Strain CCAP 1566-1 (Lane 2) and a no-template control (Lane 3); arrow indicates position of 1316 bp PCR product. (b,c) Specificity-screening of respective primer sets fNp-Hxe23b1/rNp-Hx49 and fNp-Hx43a1/rNp-Hx49 used in PCR of N. pemaquidensis AGD Strains PA027 (Lanes 1) and ATCC 50172 (Lanes 2), freeliving Strains ATCC 30735 (Lanes 3) and CCAP 1560-4 (Lanes 4), and non-target species P. pagei Strain CCAP 1566-1 (Lanes 5) and putative Paraflabellula hoguae gill isolate UP 1-6 (Lanes 6); arrows indicate respective positions of (b) ca. 1250 bp and

(c) ca. 491 bp PCR products. Lanes M: New England Biolabs 1 kb DNA ladder 
origin of the isolate. The expected molecular sizes of specific PCR products produced from these primer sets were ca. 1316, 1250 and 491 bp respectively. A single amplicon of the expected molecular size was produced using all primer sets, indicating that the respective primers specifically amplified the targeted 18S rDNA region from $N$. pemaquidensis DNA. In contrast, no amplification product was produced from DNA extracted from a putative Paraflabellula hoguae isolate cultured from Atlantic salmon gills, or from Pseudoparamoeba pagei (Fig. 1). In addition, none of the candidate diagnostic primers were complementary to other potentially occurring marine organisms when subjected to BLAST analyses.

\section{Specificity and efficacy of Neoparamoeba pemaquidensis nested PCR}

Nested Neoparamoeba pemaquidensis-specific PCR utilising 2 separate primer sets was found to be specific for all strains of $N$. pemaquidensis, while not crossreacting with DNA from non-target organisms (Fig. 2).
The nested PCR did not cross-react with the closely related species $N$. aestuarina, nor with the nonparasomal but morphologically similar Pseudoparamoeba pagei. Specificity-testing of the nested PCR showed no amplification of $N$. aestuarina with the $N$. pemaquidensis-specific primer set fNp-Hxe23b1/ rNp-Hx49, while cross-specific amplification occurred using primer set fNp-Hx43a1/rNp-Hx49 (Fig. 2). This confirmed that primers fNp-Hx43a1 and $\mathrm{rNp}-\mathrm{Hx} 49$ annealed with $N$. aestuarina 18S rDNA, while primer fNp-Hxe23b1 did not, as predicted by direct-sequence analyses. None of the diagnostic primers reacted with Atlantic salmon DNA, allowing PCR detection of the AGD parasite in samples associated with fish tissues without interference from host DNA. No variation in specificity was observed between single-step PCR amplification and secondary amplification in the nested 2-step PCR procedure using the $N$. pemaquidensisspecific primer set fNp-Hxe23b1/rNp-Hx49 (Fig. 2). The nested PCR was able to detect down to ca. $40 \mathrm{~N}$. pemaquidensis cells suspended in sterile seawater with confidence (Fig. 3), but lower cell numbers were not tested.
Fig. 2. Relative specificities of singlestep PCR using (a) primer set fNp$\mathrm{Hx} 43 \mathrm{a} 1 / \mathrm{rNp}-\mathrm{Hx} 49$ and (b) Neoparamoeba pemaquidensis-specific primer set $\mathrm{fNp}-\mathrm{Hxe} 23 \mathrm{~b} 1 / \mathrm{rNp}-\mathrm{Hx} 49$, and (c) N. pemaquidensis-specific primer set fNp-Hxe23b1/rNp-Hx49 when used as secondary primers in the nested 2-step PCR protocol. N. pemaquidensis strains tested included Tasmanian AGD Strains PA 027 (Lanes 1), PA 010 (Lanes 2), PA 011 (Lanes 3), and PA 111 (Lanes 4), Reference Strains ATCC 30735 (Lanes 5), ATCC 50152 (Lanes 6), CCAP 1560-4 (Lanes 7), CCAP 1560-5 (Lanes 8), and Irish AGD Strain AVG 8194 (Lanes 9). Non-target species included Pseudoparamoeba pagei Strain CCAP 1566-1 (Lanes 10), N. aestuarina strain CCAP 1560-7 (Lanes 11), putative Paraflabellula hoguae gill isolates UP 1-6 (Lanes 12) and UP 4a-2 (Lanes 13), and Atlantic salmon DNA (Lanes 14 and 15). Notemplate controls (Lanes 16) were also included. Note cross-reactivity of fNpHx43a1/rNp-Hx49 primer set for $N$. aestuarina (Lanes 11), that is absent with the $N$. pemaquidensis-specific primer set fNp-Hxe23b1/rNp-Hx49. Arrows indicate respective positions of (a) ca. $491 \mathrm{bp}$ and (b,c) ca. $1250 \mathrm{bp}$ PCR products. Lanes M: Invitrogen $1 \mathrm{~kb}$ DNA ladder

\section{$\begin{array}{llllllllllllllllll}\mathrm{M} & 1 & 2 & 3 & 4 & 5 & 6 & 7 & 8 & 9 & 10 & 11 & 12 & 13 & 14 & 15 & 16 & \mathrm{M}\end{array}$}

(a)

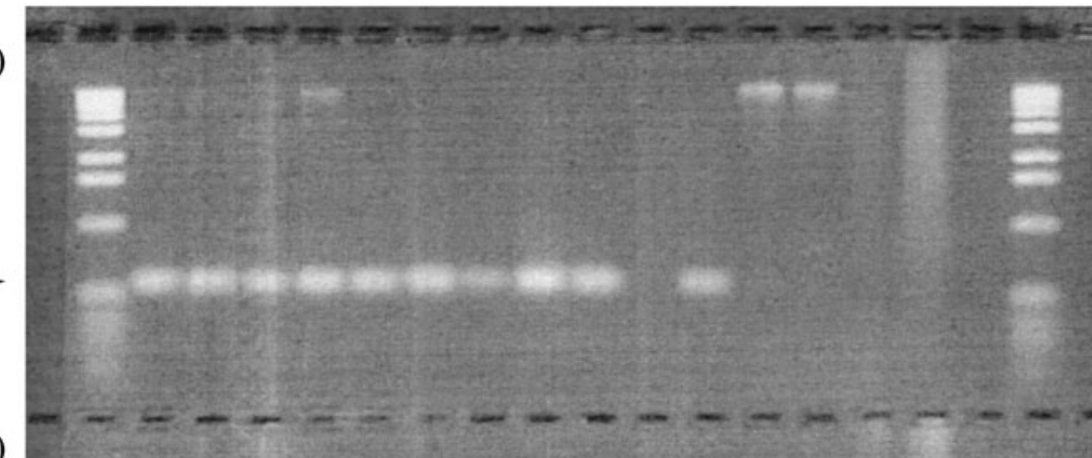

(b)

(c)

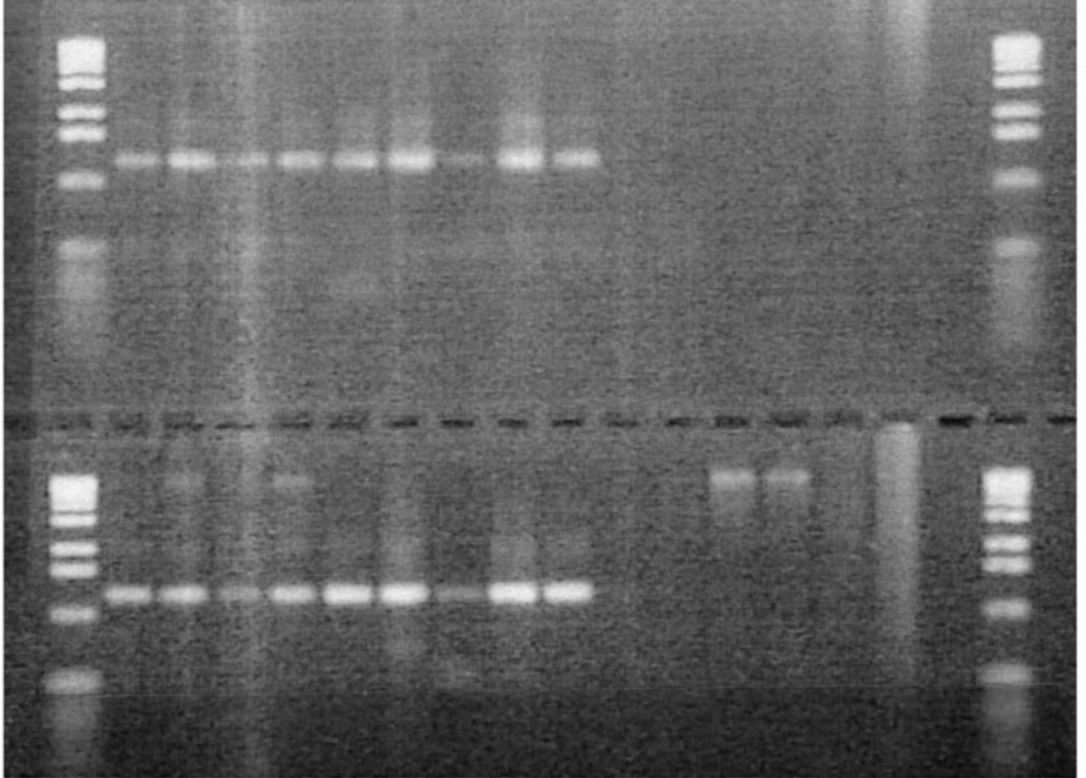




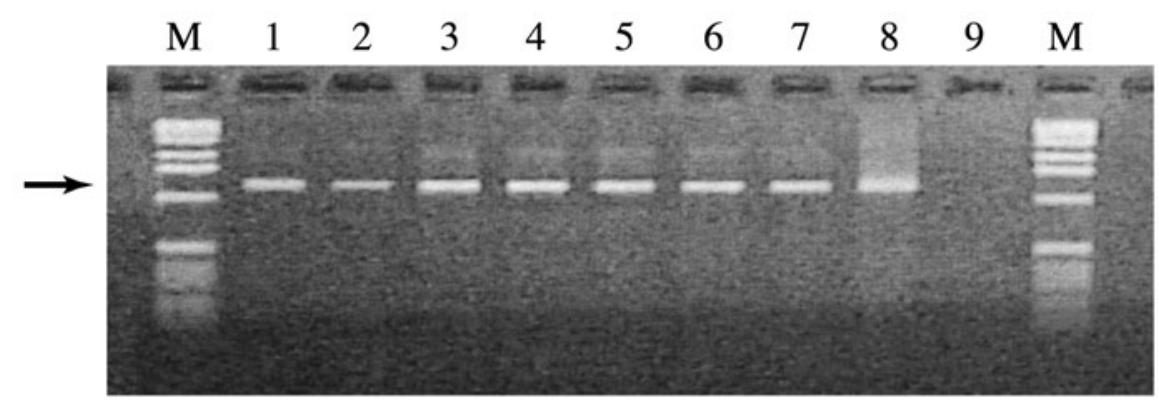

Fig. 3. Neoparamoeba pemaquidensis. Detection of Strain PA 027 cells suspended in filter-sterilised seawater by species-specific, nested 2-step PCR. Respective cellular DNA templates were extracted from dilutions containing 2560 cells (Lane 1), 1280 cells (Lane 2), 640 cells (Lane 3), 320 cells (Lane 4), 160 cells (Lane 5), 80 cells (Lane 6), and 40 cells (Lane 7). Control reactions included amplification of $30 \mathrm{ng}$ cellular DNA prepared from cells harvested directly from agar culture of Strain PA 027 (Lane 8), and a no-template control (Lane 9). Arrow indicates position of $1250 \mathrm{bp}$ PCR product. Lanes M: Invitrogen 1 kb DNA ladder

\section{Application of Neoparamoeba pemaquidensis PCR to field-based samples}

Replicate biofilm cultures from each of 5 net-pens (Pens P1 to P5) were obtained at Weeks 2 and 8 of a 10 wk pen-netting antifouling-treatment study. PCR was used to screen 25 cultured biofilm samples consisting of 5 samples from each pen at Week 2 and 15 cultured biofilm samples consisting of 3 samples from each pen at Week 8 (Fig. 4). Neoparamoeba pemaquidensis was detected by PCR in net biofilm sampled from all antifouling treated net-pens (P1 to P3) and from 1 untreated control pen, P5, at both Weeks 2 and 8 of the study. In contrast, N. pemaquidensis was not detected by PCR in any of the samples from the second untreated control pen, P4. The total percentage PCRpositive samples obtained for net-pens treated with water-based synthetic latex antifoulant (1 pen: P1), copper-based antifoulant (2 pens: P2 and P3), and untreated pens (2 pens: P4 and P5) were 40, 50 and $20 \%$ respectively at Week 2; and 33, 33 and $17 \%$ respectively at Week 8 . In addition to the antifouling treatment study, 15 other net biofilm cultures from miscellaneous sea-pens located at a different Tasmanian farm site were subjected to DNA analysis; of these $53 \%$ were PCR-positive for N. pemaquidensis. Furthermore, 2 of the ethanol-preserved amoeba culture suspensions prepared from chinook salmon gills in New Zealand were positive for $N$. pemaquidensis following amplification by nested PCR.

\section{Sequence confirmation of PCR-positive samples}

DNA sequences were obtained for nested PCR products amplified from 2 randomly selected cultureenriched biofilm samples from Atlantic salmon seapens in Tasmania and 2 chinook salmon gill cultures from New Zealand. The DNA sequences of amplicons obtained from net microfouling biofilms were homologous with the 18S rDNA of Neoparamoeba pemaquidensis, with $99.0 \%$ sequence similarity to Tasmanian AGD Strain PA 027 when 1212 bases were aligned and compared. Sequences from both biofilm samples

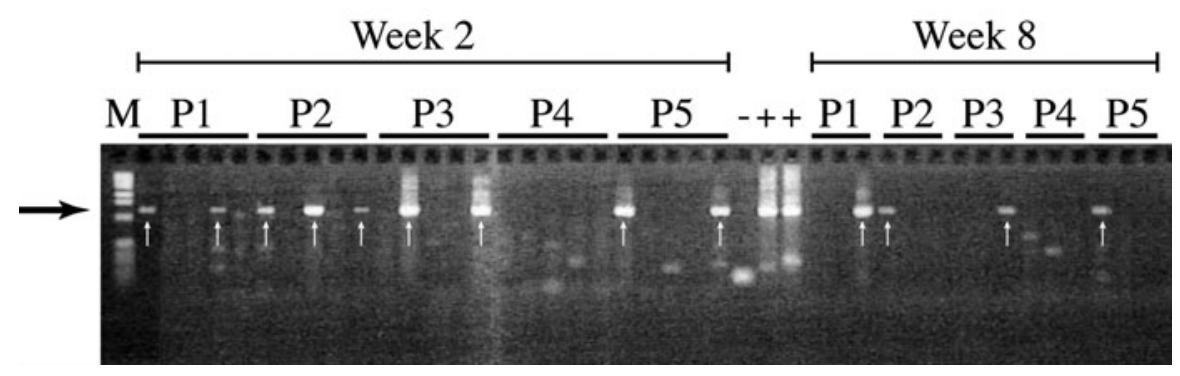

Fig. 4. Neoparamoeba pemaquidensis-specific nested PCR of enriched biofilm (microfouling) samples collected from netting of 5 sea-pens at Atlantic salmon farm site in Tasmania, during $10 \mathrm{wk}$ antifouling paint treatment trial. Netting from sampled pens had either been treated with water-based synthetic latex antifouling paint (Pen P1), a copper-based antifouling paint (Pens P2 and P3), or were untreated controls (Pens P4 and P5). Biofilm samples from same net-pens (P1 to P5) collected at Week 2 (5 samples per net-pen) and Week 8 (3 samples per net-pen) of the trial were tested by PCR. Control reactions included amplification of 30 ng cellular DNA prepared from cells harvested directly from agar cultures of $N$. pemaquidensis Strains ATCC 50152 and PA 027 (Lanes +), and a no-template control (Lane -). Large arrow indicates position of expected ca. 1250 bp PCR product; small white arrows indicate PCR-positive samples. Lane M: Invitrogen $1 \mathrm{~kb}$ DNA ladder 
were identical. Similarly, amplicon sequences from chinook salmon gill cultures were homologous with $N$. pemaquidensis PA 0127 18S rDNA, with $98.4 \%$ sequence similarity over 925 bases. However, the true extent of sequence divergence between $N$. pemaquidensis strains in the farm sample cultures and index AGD strains in Table 1 could not be determined since sequences from the entire 18S rDNA were not available for comparison.

\section{DISCUSSION}

The parasitic agent of AGD in sea-farmed Atlantic salmon in Tasmania was found by morphological and ultrastructural comparisons to most closely resemble Neoparamoeba pemaquidensis (Kent et al. 1988, Roubal et al. 1989, Munday et al. 1990). Outbreaks of histopathologically identical AGD have also affected sea-farmed salmonids in the USA and several European countries (Kent et al. 1988, Palmer et al. 1997, Munday et al. 2001). Although paramoebae from these cases were immunologically reactive with antisera prepared from Tasmanian isolates, there remained insufficient evidence to conclude that the various AGD isolates belonged to the same species. Using 18S rDNA sequence data, we have now confirmed that AGD isolates of paramoeba from Tasmania are homologous and identical to the species $N$. pemaquidensis. The Tasmanian isolates possessed greater than $98 \%$ sequence similarity with both parasitic and free-living isolates of $N$. pemaquidensis originating from the USA and UK. Sequence homogeneity among strains isolated from different countries in 3 continents also supported previous findings that $N$. pemaquidensis is a widely distributed marine species (Page 1973).

The genus Neoparamoeba currently includes 2 species, N. pemaquidensis and N. aestuarina (Page 1970, 1987). Free-living trophozoites of both species have been found in similar marine environments and are morphologically and ultrastructurally similar, making cells difficult to differentiate (Page 1970, Cann \& Page 1982). In the current study, analysis of $18 \mathrm{~S}$ rDNA sequences was able to distinguish $N$. pemaquidensis and $N$. aestuarina as 2 separate but closely related species. The levels of sequence similarities among a diverse collection of $N$. pemaquidensis strains (maximum sequence dissimilarity of $1.9 \%$ ) were consistent with a single homologous sequence type suggested for putative definition of species within another gymnamoeboid genus, Acanthamoeba (Stothard et al. 1998). In contrast, $N$. aestuarina had at least $4.3 \%$ sequence dissimilarity with strains of $N$. pemaquidensis. The Neoparamoeba spp. were not homologous to any other protistan taxa that presently exist in the eukaryotic 18S rDNA sequence database. Recent preliminary phylogenetic analyses based on 18S rDNA sequence data suggest that $N$. pemaquidensis and $N$. aestuarina represent a distinct clade independent of other marine Gymnamoebia (Fiala \& Dyková 2003), including the morphologically similar but non-parasomal amoeba Pseudoparamoeba pagei (Page 1987, Elliott et al. 2001).

A specific detection method for Neoparamoeba pemaquidensis is required for ecological and environmental studies, since the AGD-causing organism is closely related to $N$. aestuarina and possibly other as yet uncharacterised members of the genus. Currently available diagnostic methods for the AGD parasite are mainly based on immunodetection, either by IFAT or immuno-dot blot (Howard \& Carson 1993, DouglasHelders et al. 2001). However, polyclonal antisera developed for $N$. pemaquidensis cross-react with $N$. aestuarina and Pseudoparamoeba pagei (DouglasHelders et al. 2001), although not with a range of other more distantly related amoebae found co-associated with gills of AGD-affected fishes (Howard \& Carson 1993). This cross-specificity may not be important for detection of $N$. pemaquidensis in heavily infected gill samples or from culture cloned isolates, but presents a potential limitation to detection in non-purified cultures or environmental samples where higher numbers of immunologically related organisms may be present. Analysis of 18S rDNA sequences has enabled us to develop a diagnostic PCR protocol specific for $N$. pemaquidensis.

The 18S rRNA genes of some eukaryotic taxa contain unique expansion sequence segments that are highly variable between phylogenetically divergent or nonrelated organisms (Stothard et al. 1998, Sims et al. 1999). These sequence segments are situated in nonconserved regions of the gene and are often responsible for the variations in nucleotide length observed between 18S rDNA of divergent organisms. The design of 4 oligonucleotide PCR primers for Neoparamoeba pemaquidensis was based on sequence sites located within 18S rDNA expansion segments observed in 2 current species of the genus Neoparamoeba. These non-conserved gene segments were shared by closely related $N$. pemaquidensis and $N$. aestuarina, but were absent from or very different in all other representative taxa examined. Consequently, 3 of the primers had respective annealing sites present in both Neoparamoeba species. However, we were able to identify 1 primer site in $N$. pemaquidensis $18 \mathrm{~S}$ rDNA that allowed differentiation from $N$. aestuarina. PCR utilising a forward primer corresponding to this annealing site together with a co-specific reverse primer was shown to specifically amplify $N$. pemaquidensis DNA to the exclusion of $N$. aestuarina. None 
of the diagnostic primers cross-reacted with other taxa used for PCR-testing.

While single-step PCR using the species-specific primer set could successfully identify Neoparamoeba pemaquidensis cells from culture-purified isolates, we also developed a nested 2-step PCR protocol for potential application to non-purified cultures from field samples, or directly from non-enriched environmental samples. The protocol relied on a semi-specific primary amplification step followed by secondary amplification using a nested $N$. pemaquidensis-specific primer set. The semi-specific, first-round primers were selected to maximise the concentration of target DNA template for the secondary PCR step while minimising possible masking of target DNA by excessive accumulation of non-target 18S rDNA expected from samples containing mixed protistan and other eukaryotic fauna. Second-round PCR essentially confirmed that $N$. pemaquidensis $18 \mathrm{~S}$ rDNA was amplified in the first round, as well as increasing the sensitivity of detection for the target species by cumulative PCR cycling (Barlough et al. 1995). N. pemaquidensis-specific PCR did not amplify DNA of the non-parasomal marine gymnamoebae Pseudoparamoeba pagei (Page 1979) or Atlantic salmon gill isolates identified by $18 \mathrm{~S}$ rDNA sequences in this study as Paraflabellula hoguae (Amaral Zettler et al. 2000). The ability of the diagnostic PCR to detect $N$. pemaquidensis to the exclusion of non-related amoebae is important, since the latter may form part of a complex amoeboid fauna previously detected in gills of AGD-infected salmon reared in Tasmanian sea-pens (Howard \& Carson 1992).

The threshold of PCR detection was not determined for a particular sample type in the present study, although a strong amplification product was consistently obtained for ca. 40 Neoparamoeba pemaquidensis cells seeded into sterilised seawater and subjected to DNA extraction. Suspensions harvested from enrichment cultures would be expected to contain considerably larger numbers of amoeba cells (DouglasHelders et al. 2001). Nested PCR was able to detect the presence of $N$. pemaquidensis in culture-enriched net biofilm (microfouling) samples collected from 2 Atlantic salmon farm sites in southeast Tasmania. This was consistent with positive IFAT detection of $N$. pemaquidensis in cultured net biofouling samples by Tan et al. (2002), suggesting that pen-netting might be a significant environmental reservoir for AGD. Netpen surfaces and associated biofouling may provide favourable substrates for the attachment of $N$. pemaquidensis cells, a prerequisite for population growth (Martin 1985). Biofilm samples collected from net-pens that had been respectively treated with 2 types of commercial antifouling paint had an overall higher incidence of $N$. pemaquidensis than samples from untreated pens. The effects of antifoulants on the dynamics and composition of net-fouling organisms appear to contribute positively to the distribution of $N$. pemaquidensis in that environment (Douglas-Helders et al. 2003). PCR detection of N. pemaquidensis prevalence in respective cultured biofilm samples from untreated nets and those treated with a copper-based antifoulant correlated well with results obtained by IFAT screening of equivalent but independently processed samples (Douglas-Helders et al. 2003). Good agreement between these unrelated tests served to validate the positive detection of $N$. pemaquidensis by both PCR and IFAT, and suggested that immunologically cross-reactive amoebae may be absent or occurred in negligible numbers in the net biofouling cultures. Direct validation of the nested PCR products by DNA-sequencing further confirmed that N. pemaquidensis was specifically detected in the net biofilm samples.

The ability to distinguish between Neoparamoeba pemaquidensis and N. aestuarina is an important consideration for future ecological and pathological studies of AGD. Morphological and ultrastructural comparisons were unable to distinguish $N$. aestuarina Strain CCAP 1560-7, from paramoebae that caused AGD in non-salmonid fish, turbot and European seabass (Dyková et al. 1998, 2000). In contrast, nested PCR was able to confirm that paramoeba responsible for AGD in New Zealand chinook salmon was $N$. pemaquidensis, demonstrating its usefulness for the specific identification of the AGD parasite. We have thus shown conclusively in this study that AGD affecting 3 different salmonid species sea-farmed in 4 countries, namely the USA (coho salmon), New Zealand (chinook salmon), Ireland and Australia (Atlantic salmon), were associated with the uniquitous paramoeba species $N$. pemaquidensis. Whether all cases of AGD are due to $N$. pemaquidensis, or can also be caused by other parasitic Neoparamoeba species, is unclear (Dyková et al. 2000, Fiala \& Dyková 2003). Recent analysis of new $18 \mathrm{~S}$ rDNA sequence data has indicated that a related Neoparamoeba sp. distinct from both $N$. pemaquidensis and $N$. aestuarina may be associated with some cases of AGD in seawater-reared turbot in Spain (Fiala \& Dyková 2003). Paramoeba isolates from related and future AGD cases could be subjected to identity confirmation using the $N$. pemaquidensis-specific PCR described in this study. To date, $N$. aestuarina has only been reported as free-living trophozoites and has not been associated with disease in fishes.

Although DNA-based detection of Neoparamoeba pemaquidensis has mainly been applied to cultureenriched field samples in this study, the PCR assay could also be potentially optimised for direct detection in various environmental samples without prior enrich- 
ment. We have detected $N$. pemaquidensis directly in macerated net macrofouling organisms, including a common bryozoan species, using our nested PCR protocol (data not shown). Tan et al. (2002) also detected the presence of paramoeba on a number of macrofouling species growing on Tasmanian Atlantic salmon pens using IFAT on culture-enriched samples. Important factors that influence the efficacy of PCR detection in crude samples include distribution of the target organism and the effects of possible inhibitors to DNA extraction and PCR amplification within the sample matrix (Hiney 1997). As such, field surveys for $N$. pemaquidensis by PCR should involve a systematic approach to sampling, since choice of appropriate DNA extraction strategies and validation of PCR results are dependent on each sample type and the inherent matrix examined (Hiney 1997, Cunningham 2002). The continuing severe impacts of AGD on the sea-farming of Atlantic salmon in Tasmania have led to an increasing interest in assessing the distribution and ecology of $N$. pemaquidensis in the associated marine environment, with the aim of developing better farmmanagement strategies for controlling the disease. Recent studies have investigated the distribution of paramoeba cells remaining in the gills of dead salmon (Douglas-Helders et al. 2000), in wild-caught indigenous fish species (Douglas-Helders et al. 2002), and in biofilm and macrofouling organisms associated with pen-netting as well as in the surrounding water column (Tan et al. 2002). The diagnostic PCR developed in the present study provides, for the first time, a highly specific detection and identification method for $N$. pemaquidensis that will facilitate future related ecological and epidemiological studies of AGD.

Acknowledgements. This work was funded by the Fisheries Research and Development Corporation of Australia (FRDC Project 98/209). The authors wish to thank M. DouglasHelders, C. Tan, and D. Zilberg of the School of Aquaculture, Tasmanian Aquaculture and Fisheries Institute, University of Tasmania, for donation of amoeba cells and assistance in obtaining Tasmanian field samples. We would also like to thank C. Anderson of the Wallaceville Research Centre, Ministry of Agriculture and Forestry, New Zealand, and R. Palmer from the Aquatic Veterinary Group, National Diagnostic Centre, University of Galway, Ireland, for their kind donations of overseas cellular material, and are grateful to T. Wagner of the Fish Health Unit, Department of Primary Industries Water and Environment, Tasmania, for her work and time in maintaining the amoeba cultures used in this study.

\section{LITERATURE CITED}

Altschul SF, Gish W, Miller W, Myers EW, Lipman DJ (1990) Basic local alignment search tool. J Mol Biol 215:403-410 Amaral Zettler LA, Nerad TA, O'Kelly CJ, Peglar MT, Gillevet PM, Silberman JD, Sogin ML (2000) A molecular reassessment of the leptomyxid amobae. Protist 151:275-282
Ausubel FM, Brent R, Kingston RE, Moore DD, Seidman JG, Smith JA, Struhl K (1998) Current protocols in molecular biology. John Wiley \& Sons, New York

Barlough JE, McDowell TS, Milani A, Bigornia L, Slemenda SB, Pieniazek NJ, Hedrick RP (1995) Nested polymerase chain reaction for detection of Enterocytozoon salmonis genomic DNA in chinook salmon Oncorhynchus tshawytscha. Dis Aquat Org 23:17-23

Cann JP, Page FC (1982) Fine structure of small free-living Paramoeba (Amoebida) and taxonomy of the genus. J Mar Biol Assoc UK 62:25-43

Clark A, Nowak BF (1999) Field investigations of amoebic gill disease in Atlantic salmon, Salmo salar L., in Tasmania. J Fish Dis 22:433-443

Cunningham CO (2002) Molecular diagnosis of fish and shellfish diseases: present status and potential use in disease control. Aquaculture 206:19-55

Douglas-Helders (G)M, Nowak B, Zilberg D, Carson J (2000) Survival of Paramoeba pemaquidensis on dead salmon: implications for management of cage hygiene. Bull Eur Assoc Fish Pathol 20:167-169

Douglas-Helders (G)M, Carson J, Howard T, Nowak B (2001) Development and validation of a new dot blot test for the detection of Paramoeba pemaquidensis (Page) in fish. J Fish Dis 24:273-280

Douglas-Helders GM, Dawson DR, Carson J, Nowak BF (2002) Wild fish are not a significant reservoir for Neoparamoeba pemaquidensis (Page, 1987). J Fish Dis 25:569-574

Douglas-Helders GM, Tan C, Carson J, Nowak BF (2003) Effects of copper-based antifouling treatment on the presence of Neoparamoeba pemaquidensis Page, 1987 on nets and gills of reared Atlantic salmon (Salmo salar). Aquaculture 221:13-22

Dyková I, Novoa B (2001) Comments on diagnosis of amoebic gill disease (AGD) in turbot, Scophthalmus maximus. Bull Eur Assoc Fish Pathol 21:40-44

Dyková I, Figueras A, Novoa B (1995) Amoebic gill infection of turbot, Scophthalmus maximus. Folia Parasitol (České Budějovice) 42:91-96

Dyková I, Figueras A, Novoa B, Fernandez-Casal JF (1998) Paramoeba sp., an agent of amoebic gill disease of turbot Scophthalmus maximus. Dis Aquat Org 33:137-141

Dyková I, Figueras A, Peric Z (2000) Neoparamoeba Page, 1987: light and electron microscopic observations on six strains of different origin. Dis Aquat Org 43:217-223

Elliott NG, Wong F, Carson J (2001) Detection and abundance of Paramoeba species in the environment. Project 98/209. Fisheries Research and Development Corporation, Canberra

Elwood HJ, Olsen GJ, Sogin ML (1985) The small-subunit ribosomal RNA gene sequences from the hypotrichous ciliates Oxytricha nova and Stylonychia pustulata. Mol Biol Evol 2:399-410

Fiala I, Dyková I (2003) Molecular characterisation of Neoparamoeba strains isolated from gills of Scophthalmus maximus. Dis Aquat Org 55:11-16

Findlay VL, Helders M, Munday BL, Gurney R (1995) Demonstration of resistance to reinfection with Paramoeba sp. by Atlantic salmon, Salmo salar L. J Fish Dis 18:639-642

Hillis DM, Dixon MT (1991) Ribosomal DNA: molecular evolution and phylogenetic inference. Q Rev Biol 66:411-453

Hiney M (1997) How to test a test: methods of field validation for non-culture based detection techniques. Bull Eur Assoc Fish Pathol 17:245-250

Howard T, Carson J (1992) Studies of amoeba associated with amoebic gill disease in Atlantic salmon. In: Valentine P (ed) Proc Saltas Research and Development Review 
Seminar. Salmon Enterprises of Tasmania, Dover, Tasmania, p 101-122

Howard T, Carson J (1993) Verification that Paramoeba species are consistently associated with gill damage in fish affected with amoebic gill disease. In: Valentine P (ed) Proc Saltas Research and Development Review Seminar. Salmon Enterprises of Tasmania, Dover, Tasmania, p 69-80

Kent ML, Sawyer TK, Hedrick RP (1988) Paramoeba pemaquidensis (Sarcomastigophora: Paramoebidae) infestation of the gills of coho salmon Oncorhynchus kisutch reared in sea water. Dis Aquat Org 5:163-169

Martin RE (1985) Population growth in stationary and suspension culture of Paramoeba pemaquidensis Page (Amoebida, Paramoebidae). J Protozool 32:738-739

Medlin L, Elwood HJ, Stickel S, Sogin ML (1988) The characterization of enzymatically amplified eukaryotic 16S-like rRNA-coding regions. Gene 71:491-499

Munday BL, Foster CK, Roubal FR, Lester RJG (1990) Paramoebic gill infection and associated pathology of Atlantic salmon, Salmo salar, and rainbow trout, Salmo gairdneri, in Tasmania. In: Perkins FO, Cheng TC (eds) Pathology in marine science. Academic Press, San Diego, p 215-222

Munday BL, Zilberg D, Findlay V (2001) Gill disease of marine fish caused by infection with Neoparamoeba pemaquidensis. J Fish Dis 24:497-507

Page FC (1970) Two new species of Paramoeba from Maine. J Protozool 17:421-427

Page FC (1973) Paramoeba: a common marine genus. Hydrobiologia 41:183-188

Page FC (1974) Rosculus ithacus Hawes, 1963 (Amoebida. Flabellulidae) and the amphizoic tendency in amoebae. Acta Protozool 13:143-154

Editorial responsibility: Wolfgang Körting,

Hannover, Germany
Page FC (1979) Two genera of marine amoebae (Gymnamoebia) with distinctive surface structures: Vannella Bovee, 1965, and Pseudoparamoeba n. gen., with two new species of Vannella. Protistologica 15:245-257

Page FC (1987) The classification of 'naked' amoebae (phylum Rhizopoda). Arch Protistenkd 133:199-217

Palmer R, Carson J, Ruttledge M, Drinan E, Wagner T (1997) Gill disease associated with Paramoeba, in sea reared Atlantic salmon in Ireland. Bull Eur Assoc Fish Pathol 17: 112-114

Rodger HD, McArdle JF (1996) An outbreak of amoebic gill disease in Ireland. Vet Rec 139:348-349

Roubal FR, Lester RJG, Foster CK (1989) Studies on cultured and gill-attached Paramoeba sp. (Gymnamoebae: Paramoebidae) and the cytopathology of paramoebic gill disease in Atlantic salmon, Salmo salar L., from Tasmania. J Fish Dis 12:481-492

Sims GP, Rogerson A, Aitken R (1999) Primary and secondary structure of the small-subunit ribosomal RNA of the naked, marine amoeba Vannella anglica: phylogenetic implications. J Mol Evol 48:740-749

Stothard DR, Schroeder-Diedrich JM, Awwad MH, Gast RJ and 5 others (1998) The evolutionary history of the genus Acanthamoeba and the identification of eight new $18 \mathrm{~S}$ rRNA gene sequence types. J Eukaryot Microbiol 45: 45-54

Tan CKF, Nowak BF, Hodson SL (2002) Biofouling as a reservoir of Neoparamoeba pemaquidensis (Page, 1970), the causative agent of amoebic gill disease in Atlantic salmon. Aquaculture 210:49-58

Zilberg D, Munday BL (2000) Pathology of experimental amoebic gill disease in Atlantic salmon, Salmo salar L., and the effect of pre-maintenance of fish in sea water on the infection. J Fish Dis 23:401-407

Submitted: September 17, 2003; Accepted: January 5, 2004 Proofs received from author(s): June 26, 2004 